\title{
The Folk Culture and Cultural Identity in Grimm's Fairy Tales
}

\author{
Jing Li \\ School of Fore ign Language \\ Hubei University of Automotive Technology \\ Shiyan, P. R. China
}

\begin{abstract}
Grimm's Fairy Tales covers almost the entire contents of the folklore motif, induding animal stories, personal stories, monster stories, jokes and anecdotes. It is a rare model for the study on folk literature. From the perspective of cultural identity, the German folk culture characteristics shown in this legendary literary works were analyzed, with particular attention to the culture-shaped political significance and cultural value of the work.
\end{abstract}

Keywords-Grimm's fairy tales; folk culture; cultural value; cultural

\section{INTRODUCTION}

Grimm's Fairy Tales was originally entitled "Child and Family Fairy Tales" (Kinder- und Hausmärchen, KHM). As a master of European folk literature, it employed mysterious imagery, legendary plot to build a world beyond the reality of eternal life, with accumulation of rich cultural connotation, carrying multifaceted cultural connotation including nation, history and many other. As the result of folk wisdom, it retains many of the original folk culture show component in between the lines, with a strong stigma of social development, which makes this work enduring. When looking into the typical folk cultural symbols, it is in line with the long formed certain recognizing of the most significant thing for this the German national community live together, its core is the identity of the fundamental cultural value. No wonder Jacob Grimm once wrote, "All my work is dedicated to my homeland. For these works drew power only from the land of the motherland. Consciously or unconsciously, I felt that our country's guidance is the most correct. All we have achieved should first of all be attributed to our motherland."

\section{TYPICAL FOLK CULTURE SYMBOLS IN GRIMM'S FAIRY TALES}

\section{A. Characters as Symbols}

A large number of characters portrayed in the work, including animals, elves, dwarves, etc., which are in fact the imprints of human life in a long history. They were unconsciously given a special meaning, and entering the field of "cultural texts". Originally a serious threat to the survival of mankind alien forces of nature gradually be given social attributes, oppressors and became a symbol of the forces of evil, including the fearsome beasts, such as the dragon, lion, wolf, etc., at the same time, people are more willing to talk about those with people, animals and plants experienced man off the difficult story of the wizard, the animals are often petite, little threat to humans, such as ducks, deer, and other ants, they equate with the people, to the opening speech. Actually, this is the people of the natural world anthropomorphic illusions, cognitive primitive agricultural society, deeply permeated with primitive cultural atmosphere. Further, as the Neanderthals, fishing and hunting, witchcraft, giant, dwarf and other primitive images abound in fairy tales. For example KHM53 Snow White in the Seven Dwarfs as shelter princess as she undid almost to life ribbon, unplug the poison comb on her head, was found dead after she cried and cried and cried full three day, he showed great compassion, when you see the prince on the "dead" in a deep feeling of Snow White and took a glass coffin to the prince. There KHM13 Forest Three Villain Children, KHM55 Oddly Named Dwarf Children, and so on, people feel the presence of human warmth. Dwarves here represent one side, and closely related to human light, is sublime incarnation.

In fairy tales, the development of social productivity is closely related to the change of attitudes towards traditional occupation. For instance, Jacob in 1808 in Hesse collected an anonymous oral story-based, writing KHM55 Oddly Named Dwarf Children, the narrative relates to a means of textiles to improve their social status plight farm girl. Miller's daughter by helping dwarves to spin straw into gold, managed to marry the king wife. KHM24 Mrs. Horace, KHM188 Spindle, Shuttle, and Needle, such stories have focused on the "girl" weavers of diligence and hard work, they finally won the Prince.

\section{B. Environments as Symbols}

Let's look at the important background in Grimms ' Fairy Tales - forest. Many fairy tale plot development has a direct or indirect participation in the forest. These recurring forest background, the overall performance is low social productive forces, it revealed the primitive human totem worship of the forest. The book is the story of forest complex has 168 , more than 60 percent of the entire length, very few of the vast sea and towering mountains. For example, KHM 54 "backpack, hat and horn" Three brothers boss, the second, the third into the respective are "a forest", "a forest", "a lonely forest", only to find their ideal wealth. KHM24 Mrs. Horace apple trees laden with fruit of hard-working g irl shouted, "Hey, shake me, shake me, I beckon whole apple cooked it!" Offered her help life supplies. 
KHM 21 Cinderella in the tomb of the mother tree stick, meet Cinderella oppressed desire to give her good clothes to attend the banquet, but also ultimately help Cinderella back to his prince. Why are there so many forest-related topic? Because Germany is a country of multiple forests, forests play a very important role in the transition of hu man civilization by a brutal, traditionally, German rural life and forests are closely ties, both farmers as forest grazing herd feeding place, but also the members of the royal hunting where the beast, or the woodcutter lu mberjack or hard-working place. It is a source of food and clothing of the people, the survival, coupled with evergreen trees with strong vitality, so inevitably become the object of worship, even as life has super powers to help solve their own cannot be achieved problem. Therefore, it is easy to understand why the forest trail a mong the frequently appears in the text. It includes many stories well the emergence of a lot of heroes often appear next to wells, which indicates the importance of the time in people's well in reallife.

\section{Cultural Customs as Symbols}

Another typical sign is a common Germanic custom of blood revenge. Before the establishment of the Modern State, the most important core social relationships is the family kinship. For a family member of the damage is often seen as a violation of their individual and family with his blood, and the only way to correct the damage it is blood for blood, tooth for tooth. So revenge is considered a permitted public order. It has been called the "barbaric" nations, attention to honor Germans especially, the text is no lack of similar incidents, reflecting the era in common vendetta. KHM40 Robber Fiancé Miller deluded, will marry the daughter of a robber disguised as suitors, the young girl to the robber nest after the discovery of the true face of her fiancé, escaped from the den, to his father about the whole encounter, held wedding day father and guests together to seize the robber handed him over to the court. KHM96 Three Birds pretty good queen was framed his two sisters, the king thought she gave birth to three fertility are cats and dogs, under angry her into pris on, and her three children were fishermen and magic Teachers help, and met the king to save his mother, burned two cruel aunt. Which is full of bloody revenge and vendetta.

For another example, a fairy tale stepmother frequent reflected the people's general life is not too long, so keep the marriage together time is relatively short, losing a spouse need not wait for a long time will soon remarried, such as Snow White, Cinderella stepmother is soon a success or status of the mother; the image of the ugly witch, often dressed in black, representing the forces of darkness, the witch would reflect people's dis gust mysterious power of worship and fear.

\section{SOCIAL AND HIST ORICAL BACKGROUND OF GRIMM'S FAIRY TALES}

Folk culture is always linked with the development of society and history. Grimms' Fairy Tales in the mapping out how the folk culture is closely related to the development of the German nation it? This "specific" social and historical background is necessary to give an account.
Before 1871, so-called "Holy Roman Empire of the German nation," or "First Empire" never become a centralized unified country, its territory with the rulers in Marriage, sell and redeem frequent wars and often change. It failed to build a strong central government, German-speaking central Europe large areas never form a nation-state. Holy Ro man Empire can be said to be a loose federation formed by the regional power. They formed a loose aggregate, rather than a centralized country. In this political framework, the emperor is a weak political symbols, they face strong centrifugal force around the princes helpless. Thus, it is within the formation of a unique political landscape, the "small state divide and conquer / separatis m" (Partikularis mus), each self-contained small states, do not listen to the emperor's orders, the medieval German territory has also been described as a "patched carpet." Contradiction between imperial and local government early this intensified in the seventeenth century, the Holy Roman Empire eventually led to civil war, which evolved to fulfill the EU to participate in a large-scale international war - Thirty Years War, the old empire was divided after the war into 314 states and 175 Chevalier collar, these areas of different sizes, different social structures, varying levels of economic development, but they are nothing but independence political entity, respectively, said the kingdom, Elector country, Hou, Duchy, Emirates, free imperial city, etc., are independent and sovereign, the princes of authoritarian rule; even in 1815 after Vienna and Germany still consisting of 38 sovereign states, including 34 nations and four free market. Poet Wieland in 1791, "On the general lack of common sense in Germany," which has had a deep-rooted feeling of the words: "a better understanding of our foreigners accused us it is all too real: a foreigner, when traveling long as careful a little German Empire, you will find that he saw, just to get to know the Austrians, Brandenburg, Saxon people, Palatinate, Bavarian, Hessian, Wurttemberg people, etc. etc. these people according to the level to which it belongs Empire named, some of them divided into hundreds of smaller tribal groups, than a small, but each has its form, but people just do not see the German. From History of the development of the German nation, the German was broken rule calling pattern of relatively uniform cultural pattern. From the perspective of cultural identity, can be born in the early 19th century, the German Brothers Grimm defined as people under the special social and historical background from the requirements of uniform needs, participate in literary product of social construction. While emphasizing the national cultural identity features common aesthetic values, including national collective identity, including for the construction of meaning. This association is consistent with current development needs of a society and history.

It is because there was not a German national political and cultural center, without the presence of the center means more opportunities for the center, the most significant cultural and ecological characteristics of German history is "rich diversity", this place most separatist whole growth process is accompanied by the old empire, it will inevitably be intercepted or projected in the formation of the text, the history is marked with the stigma of the Brothers Grimm. It can be said, Grimms' Fairy Tales, or even the whole of German literature before the 19th century is a cultural identity in the 
construction activity, after entering the 19th century, it shapes their cultural identity in the process of cultural integration, and continue to position itself German identity. It runs under the framework of the national culture, from the perspective of groups on the "German" selection and reconstruction, and the use of the members of the group shared knowledge to give it new meaning. This time agree with this trend attributable to the individual put their own group. The Brothers Grimm is undoubtedly pave horizons through a common text to shape the cultural identity of a collective framework, which at the time was "Fatherland."

\section{CONCLUSION}

Therefore, from these textual features, we can say, Grimms' Fairy Tales is carried by a collective history, a kind of wisdom and cultural life of labor state, reflecting the ethnic style in the history of social development, it was mapping out changes and differentiation of social productive forces of society. Its cultural vision is built on the basis of national culture and human culture above, which can even pursue a common primitive beliefs and folk heritage of all ethnic groups. For the Brothers Grimm "German" cultural identity of views reflected in this text, it is a common folk culture base, which for that era, "German" cultural identity positioning played a positive role, constitutes its recipient cultural identity.

\section{REFERENCES}

[1] J. Grimm and W. Grimm, Grimms' Fairy Tales. Nanjing: Yinlin Press, 2008.

[2] W. Liu, A Study on Fariy Tales in German Romantic Period. Beijing: Beijing Instit ute of T echnology Press, 2009.

[3] Y. Peng, Into the Enchanted Forest: A Study on Grimms' Fairy Tales. Beijing: Foreign Language Teaching and Research Press, 2010.

[4] F. Schiller. A History of the Thirty Years' War. Beijing: The CommercialPress, 2009.

[5] Z. Cai, "Contemporary Value of Folk Culture", Northwestern Journal of Ethnology, 2012 (7201), pp:208-211.

[6] X. Qian, "On Formation of Folk Culture and Characteristics of Ethnic Consciousness", World Ethno-National Studies, 2002 (3), pp:1-9. 